Vol. 1 No. 3 September 2021

\title{
PENGARUH ENTERPRISE RISK MANAGEMENT TERHADAP KINERJA PERUSAHAAN DENGAN INTELLECTUAL CAPITAL SEBAGAI VARIABEL MODERASI
}

\author{
Risa Martia Aryanti \\ risamartia22@gmail.com \\ Jurusan Akuntansi Fakultas Ekonomi dan Bisnis Universitas Mataram \\ Susi Retna Cahyaningtyas \\ susi_retnacahya@unram.ac.id \\ Jurusan Akuntansi Fakultas Ekonomi dan Bisnis Universitas Mataram \\ Iman Waskito \\ waskitoiman@unram.ac.id \\ Jurusan Akuntansi Fakultas Ekonomi dan Bisnis Universitas Mataram
}

\begin{abstract}
The study aims to determine the effect of enterprise risk management on company performance with intellectual capital as a moderating variable. The dependent variable of company performance is measured by ROE. Enterprise risk management independent variables measured content analysis based on the 2017 COSO ERM framework in the form of 20 principles that include 5 components. Intellectual capital moderation variable is measured by VAIC ${ }^{\mathrm{TM}}$. This research uses the signaling theory. The sample was obtained based on purposive sampling and produced 43 companies in property, real estate and building construction companies for the 20152019 fiscal year which were listed on the Indonesia Stock Exchange. Data were analyzed based on Moderating RegressionAnalysis (MRA). The results of this study indicate that enterprise risk management has no effect on company performance which shows the coefficient of ERM is negative, that is -0.965 with a probability of $0.336>0.05$. This result also shows that intellectual capital does not moderate the relationship between enterprise risk management andcompany performance, which shows the coefficient value of -0.047 with sig. 0.962 .
\end{abstract}

Keywords: enterprise risk management, intellectual capital, company performance

\section{PENDAHULUAN}

Saat ini kita sedang berada dalam konteks perubahan global di berbagai aspek kehidupan modern yang bersifat disruptif. Perubahan itu dinamakan VUCA World, yakni dunia yang volatile, uncertain, complex dan ambiguity. VUCA telahmenjadi istilah unik dan trendi untuk mengatakan "perubahan tak terduga". Perubahan yang sangat cepat menyebabkan ketidakpastian. Ketidakpastian ini penuh dengan risiko yang berdampak negatif, namun terdapat juga peluang yang dapat dimanfaatkan untuk mencapai tujuan organisasi. Dalam konteks ini, manajemen risiko menjadi relevan untuk diimplementasikan dengan serius pada suatu organisasi (Susmianti,2019). Salah satu implementasi unggulan management resiko adalah penerapan enterprise risk management tahun 2004 yang diprakarsai oleh COSO. COSO adalah singkatan commite of Sponsoring organization of the treadway commission dibentuk tahun 1985 dan bersifat nirlaba, sebagai upaya memerangi bersama melawan corporate fraud di USA. Lima organisasi pendirinya adalah AICPA, AAA, FEI, IIA dan IMA. Pada Juni 2017 COSO merilis perubahan kerangka kerja manajemen 
risiko yang berjudul Enterprise Risk ManagementFramework Integrating with Strategy and Performance. Framework (2017) mendefinisikan enterprise risk management sebagai berikut: "The culture, capabilities and practices, integrated with strategy-setting and performance, that organizations rely on to manage risk in creating, preserving and realizing value." Framework juli 2017 berbentukpita DNA, menggambarkan komponen - komponen ERM yang saling berkaitan dan menyatu dengan seluruh aspek/proses entitas. Bentuk pita DNA menekankan pentingnya budaya sadar resiko untuk menghadapi tantangan bisnis dengan risiko yang semakin kompleks dan saling terkait.

Penelitian ini merupakan replikasi penelitian Khan, Ali, Anjum dan Noman tahun 2019 dengan judul yang sama. Menurut hasil penelitian Khan, Ali, Anjum dan Noman (2019) menunjukkan hasil yang positif tetapi tidak signifikan antara ERM dan ROE. Selain itu, hasil penelitian saat ini menunjukkan efek moderasi positif yang signifikan dari IC antara ERM dan ROE. Dukungan pandangan berbasis sumber daya menganggap ERM dan IC sebagai sumber daya utama perusahaan. Akibatnya, sejalan dengan pandangan ini, berdampak pada ERM dan IC dapat meningkatkan kinerja perusahaan secara efisien. Dengan demikian Penelitian ini menggunakanIntellectual Capital sebagai variable moderasi. Yang artinya, Intellectual Capital mampu mempengaruhikinerja suatu perusahaan menyebabkan peneliti menduga bahwa variabel IC sebagai variabel yang mampu memperkuat atau memperlemah pengaruh Enterprise Risk Management pada kinerja perusahaan.

Objek penelitian dalam penelitian ini adalah Sektor properti, real estate dan konstruksi bangunan. Sektor properti, real estate dan konstruksi bangunan merupakan sektor besar yang mampu menyerap tenaga kerja dalam jumlah besar dan memiliki efek berantai kepada sektor - sektor ekonomi lainnya. Berdasarkan kajian Kementerian Keuangan, sektor properti menghasilkan multiplier output di atas satu yang berarti jika terdapat kenaikan pertumbuhan padasektor properti maka berdampak besar pada pertumbuhan sektor yang lain. Bila properti tumbuh $\mathrm{Rp} 1$ triliun, dampaknya $\mathrm{Rp} 1,9$ triliun untuk konstruksi, dan $\mathrm{Rp} 1,2$ triliun untuk real estate (Kencana, 2019).

Pasang surut perkembangan sektor properti di Indonesia cukup menyita perhartian investor. Dahulu bisnis di sektor properti dianggap selalu menguntungkan, namun beberapa tahun belakangan ini pertumbuhan sektor properti justru sangat rentan dipengaruhi oleh sejumlah faktor seperti perlambatan pertumbuhan ekonomi (Kurniawan,2019). Apalagi di tahun ini cukup besar lantaran sektor property di tahun 2019 juga akan dihadapkan dengan agenda pemilihan presiden (Pilpres) dan Pemilihan Legislatif(Pileg) hingga kwartal kedua 2019. Pada tanggal 29 Oktober 2019 Bursa Efek Indonesia (BEI) mencatat sektor properti, real estate, dan konstruksi bangunan melaju paling kencang sebesar 15,12\% ytd (year-todate). Tertinggi dari sembilan sektor yang ada di BEI. Pembanguan infrastuktur adalah kunci untuk pertumbuhan sektor properti di tahun 2019 (Tari, 2019). Tahun 2019 menjadi momentum pemulihan sektor properti nasional karena pada tahun ini banyakinfrastruktur yang dibangun pemerintah sudah rampung dan diyakini akan mampu menggerakkan perekonomian masyarakat di sekitarnya. Pulihnya sektor properti juga terdongkrak oleh kebijakan pemerintah yang melonggarkan kredit property/LTV dan pengurangan threshold/batas bawah harga rumah yang akan dikenakan pajak PPh 22 dan PPnBM. Sejalan dengan pernyataan data diatas peneliti memilih sektor properti, real estate dan kontruksi bangunan menjadi objek dalam penelitian ini karena ketidakpastian ekonomi nasional berdampak pula pada rendahnya pertumbuhan investasi sehinggamanajemen resiko bagi 
perusahaan yang bergerak dalam bidang properti, real estate dan konstruksi bangunan semakin menjadi suatu keharusan.

\section{KAJIAN PUSTAKA}

Signaling theory

Pencetus Signaling Theory ini adalah Spence yang melakukan penelitian dengan judul Job Market Signaling pada tahun 1973. Spence (1973)menyatakan bahwa teori ini melibatkan dua pihak, yakni pihak internal seperti manajemen yang berperan sebagai pihak yang memberikan sinyal dan pihak eksternal seperti investor yang berperan sebagai pihak yang menerima sinyal tersebut. Dengan memberikan sinyal atau isyarat artinya pihak manajemen berusaha memberikan informasi yang relevan yang dapat dimanfaatkan oleh pihak investor. Investor akan menggunakan informasi sebagai dasar memutuskan diversifikasi portofolio dan melakukan kombinasi investasi dengan preferensi risiko yang diinginkan meskipun informasi yang diberikan bersifat privat.

Siregar dan Safitri (2019) menyatakanbahwa teori signal mengindikasikan bahwa perusahaan akan berusaha untuk memberikan sinyal berupa informasi positif kepada investor potensial melalui berbagai pengungkapan dalam laporan keuangannya. Pengungkapan bisa berupa Informasi Enterprise Risk Management, Intellectual Capital, Corporate Social Responsibility, dan SustainabilityReporting. Pengungkapan tersebut tidak hanya dapat ditemukan di annual report perusahaan, tetapi juga dapat ditemukan di website perusahaan. Kinerja perusahaan

Kinerja perusahaan merupakan hal pentingyang harus dicapai oleh setiap perusahaan dimanapun, karena kinerja merupakan cerminan dari kemampuan perusahaan dalam mengelola danmengalokasikan sumber dayanya. Kinerja perusahaan sangat dinamis bagi pemangku kepentingan, investor, dan pengembangan ekonomi. Investor bisnis selalu membutuhkan pengembalian investasi yang lebih besar dan bisnis yang terorganisir dengan baik dapat membawa keuntungan yang lebih besar dalam jangka panjang bagi para investornya. Perusahaan dengan profitabilitas yang lebih besar dan kinerja keuangan mungkin memiliki unit produksi ramah lingkungan yang baik, membawa produk-produk berkualitas tinggi bagi pelanggannya, dan meningkatkan pendapatan karyawan (Mirza \& Javed, 2013). Namun, keharusan perusahaan untuk menghadapi berbagai jenis risiko untuk mencapai pengembalian yang lebih tinggi. Oleh karena itu, sangat pentingbagi manajemen untuk membedakan prospek untuk membiarkan organisasi meningkatkan laba sambil memitigasi risiko. Kinerja perusahaan dalam penelitian ini diukur melalui ROE ( Return on Equity). ROE dipilih sebagai variable dependen dalam penelitian ini karena ROE lebih mencerminkankemampuan perusahaan menggunakan modal dari setoran pemilik dan laba ditahan saja sehingga lebih mencerminkan kemampuan perusahaan dalammenghasilkan laba dengan asumsi tanpa hutangsekalipun.

\section{Enterprise risk management}

COSO ERM Framework (2017) mendefinisikan manajemen risiko sebagai berikut: "The culture, capabilities and practices, integrated with strategy-setting and performance, that organizations rely on to manage risk in creating, preserving and realizing value." Berbeda dengan COSO ERM - integrated framework, COSO ERM baru ini menghadirkan lima komponen yang sangat fundamental untuk dipenuhi oleh setiap organisasiyang ingin mengelola risiko, strategi, dan hasil kinerjanya. Lima komponen tersebut yaitu: 
1) Governance and Culture (Tata Kelola dan Budaya)

Tata kelola mengatur organisasi, memperkuat pentingnya, dan menetapkan tanggung jawab pengawasan untuk manajemen risiko perusahaan. Budaya berkaitan dengan nilai- nilai etika, perilaku yang diinginkan, dan pemahaman risiko dalam entitas.

2) Strategy and Objective-Setting (Strategi danPenentuan Tujuan)

Manajemen risiko perusahaan, strategi, dan penetapan tujuan bekerja bersama dalam proses perencanaan strategis. Selera risiko ditetapkan dan diselaraskan dengan strategi; tujuan bisnis menerapkan strategi dalam praktik yang berfungsi sebagai dasar untuk mengidentifikasi, menilai, dan merespons risiko.

3) Performance (Kinerja)

Risiko yang dapat memengaruhi pencapaian strategi dan tujuan bisnis perlu diidentifikasi dan dinilai. Risiko diprioritaskan oleh tingkat keparahan dalam konteks risk appetite. Organisasi kemudian memilih tanggapan risiko dan mengambil pandangan portofoliodari jumlah risiko yang telah diasumsikan. Hasil dari proses ini dilaporkan kepada pemangku kepentingan risiko utama.

4) Review and Revision (Penelaahan dan Revisi) Dengan meninjau kinerja entitas, organisasidapat mempertimbangkan seberapa baikkomponenmanajemen

risiko perusahaan berfungsi dari waktu ke waktu dan mengingat perubahan substansial, dan revisi apa yang diperlukan.

5) Information, Communication, and Reporting(Informasi, Komunikasi, dan Pelaporan) Manajemen risiko perusahaan memerlukanproses berkelanjutan untuk

mendapatkan berbagi informasi yang diperlukan, baik darisumber internal dan eksternal, yang mengalirnaik, turun, dan melintasi organisasi

Selain lima komponen ERM di atas, COSO merumuskan 20 prinsip yang dapat menjadi dasar pengembangan standar ERM dan pengukuran kualitas ERM di masing-masing organisasi. Prinsip- prinsip tersebut wajib dibangun dan berfungsi agar diperoleh ERM yang dapat diandalkan.

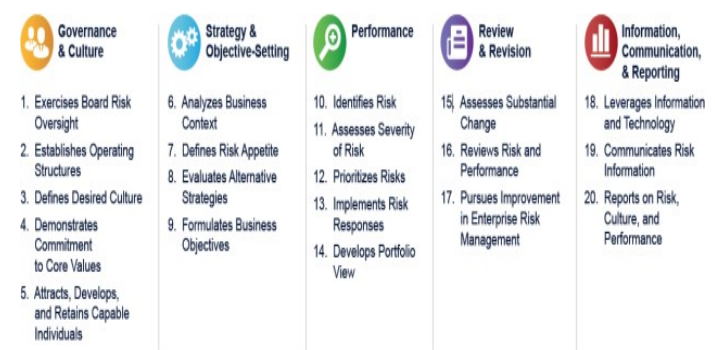

Gambar. 2.1. Prinsip Enterprise Risk Managementmenurut COSO 2017 Rerangka konseptual

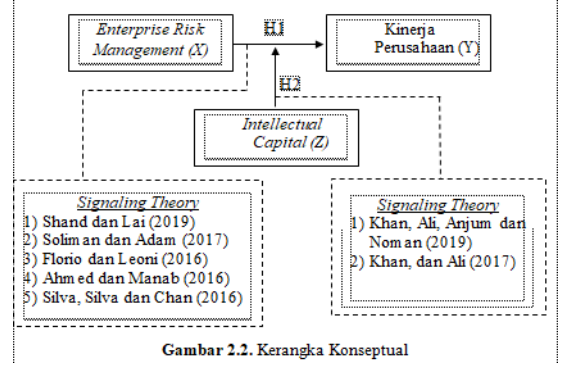


Intellectual capital

Intellectual capital (IC) merupakan sebuah informasi dan pengetahuan yang dapat diaplikasikan ke dalam sebuah pekerjaan untuk dapat menciptakan sebuah nilai di dalam perusahaan (Lestari \& Sapitri, 2016). Menurut Ulum (2009) Intellectual capital terdiri dari tiga elemen utama, yaitu human capital (modal manusai), structural capital atau organizational capital (modal organisasi), dan costumer capital atau relational capital (modal pelanggan). Berikut penjelasan mengenai tiga elemen utama intellectual capital tersebut:

1) Modal Manusia (Human Capital)

Human capital merupakan pengetahuan, keterampilan, dan kompetensi yang mencerminkan kemampuan kolektif perusahaan untuk menghasilkan solusi terbaik berdasarkan pengetahuan yang dimiliki orang-orang yang ada dalam perusahaan tersebut.

2) Modal Struktural (Structural Capital/ Organizatinal Capital)

Structural capital atau organizatinal capital merupakan kemampuan organisasi atau perusahaan dalam memenuhi proses rutinitas strukturnya yang mendukung usaha karyawan untuk menghasilkan kinerja intelektual yang optimal serta kinerja bisnis secara keseluruhan.

3) Modal Relasional (Relational Capital)

Ralational capital atau customer capital (modal pelanggan) merupakan hubungan yang harmonis yang dimiliki oleh purusahaan dengan para mitranya, baik yang berasal dari pemasok yang andal dan berkualitas berasal dari pelanggan yangloyal dan merasa puas akan pelayanan perusahaanyang berasal dari hubungan perusahaan denganpemerintah maupun dengan masyarakat sekitar.

\section{HIPOTESIS PENELITIAN}

Perkembangan bisnis saat ini mengalami kemajuan yang sangat pesat serta persaingan yang begitu ketat. Manajemen risiko adalah perhatian dasar untuk bisnis. Enterprise Risk Management (ERM) adalah salah satu alat penting yang secara efektif digunakan oleh perusahaan untuk mengurangi risiko potensial. Tujuan dasar manajemen risiko adalah memberikan pemantauan terus-menerus dari hari ke hari operasi, membuat rencana pemulihan danperingatan keseluruhan aktivasi berisiko yang terkadang memberikan pendapatan abnormal ke perusahaan (Khan dan Ali, 2017).

Enterprise risk management sebagai informasi non keuangan mampu menjadi sinyal bagi investor terkait keamanan dana yang diinvestasikan. Semakin tinggi informasi yang disampaikan perusahaan maka investor akan semakin yakin akan keamanan dana yang diinvestasikan. Investor melihatenterprise risk management disclosure merupakan sinyal positif karena melalui informasi enterprise riskmanagement disclosure maka investor dapat menilai prospek perusahaan.

Ahmed dan Manab (2016) menyelidiki pengaruh implementasi kerangka ERM dan ekuitasdewan kepemilikan pada kinerja intuisi keuangan di Nigeria. Seratus enam puluh tiga institusi merupakan sampel penelitian. Mereka mengumpulkan data dari chief risk officer, chieffinancial officer dan manajer tingkat atas lainnya dari organisasi sampel. Penelitianini menggunakan pemodelan jalur PLS-SEM dengan bantuan perangkat lunak SmartPLS 2.0 
untuk menguji kerangka penelitian. Hasil analisis menunjukkan bahwa ERM implementasi kerangka kerja dan kepemilikan ekuitas dewan memiliki pengaruh positif yang signifikan terhadap keuangan dan kinerja non-keuangan lembaga keuangan di Nigeria. Florio dan Leoni (2016) juga menemukan efek positif dari implementasi ERM pada kinerja perusahaan di perusahaan-perusahaan Italia. Demikian pula Silva, Silva dan Chan (2016) menyatakan bahwa adanya hubungan positif antara adopsi ERM dan kinerja perusahaan di Brazil, konsisten dengan sebagian besar penelitian internasional. Dengan demikian, maka hipotesis yangdiajukan sebagai berikut.

H1 : Enterprise Risk Management berpengaruhpositif terhadap Kinerja perusahaan.

Signaling theory memberikan pandangan bahwa perusahaan akan memberikan pengungkapan informasi lebih banyak secara sukarela daripada yang seharusnya untuk memberikan sinyal yang positif, sehingga perusahaan cenderung meningkatkan informasi yang diberikan pada stakeholders dengan melakukan pengungkapan dalam laporan tahunan. Investor akan memberikan penilaian yang lebih terhadap perusahaan yang memiliki intellectual capital yang tinggi (Oktari, Handayani dan Widiastuty, 2016). Khan dan Ali (2017) mengklaim bahwa perusahaan dengan IC lebih besar berada padaposisi yang baik untuk mampu bertahan dari dampak perubahan yang tidak terduga dalam ekonomi dan pasar saat ini. Perusahaan-perusahaan ini dapat mengantisipasi risiko yang terjadi dan dapat mengendalikan dengan cara yang baik. Perusahaan dengan IC yang lebih besar mengadopsi praktik ERMyang dapat berdampak sinyal positif pada pasar dan kinerja operasi perusahaan. Dukungan pandangan berbasis sumber daya menganggap ERM dan IC sebagai sumber daya utama perusahaan. Sejalan dengan pandangan ini, maka berdampak pada ERM dan IC dapat meningkatkan kinerja perusahaan secaraefisien. Hasil penelitian menunjukkan hasil yang positif tetapi tidak signifikan antara ERM dan ROE. Selain itu juga, menunjukkan efek moderasi positif yang signifikan dari IC antara ERM dan ROE. Hasil penelitian ini juga menunjukkan pentingnya modal intelektual dalam perusahaan. Dengan demikian, maka hipotesis yang diajukan sebagai berikut.

$\mathrm{H} 2$ : Intellectual Capital memoderasi hubungan antara Enterprise Risk Management dan kinerja perusahaan.

\section{METODE PENELITIAN}

Jenis penelitian yang digunakan dalam penelitian ini adalah penelitian Asosiatif dengan pendekatan kuantitatif. Objek penelitian ini dilakukanpada sektor properti, real estate dan konstruksi bangunan yang terdaftar di Bursa Efek Indonesia (BEI) pada tahun 2015-2019 dan waktu penelitianadalah pada saat pengumpulan analisis data. Jenis datdalam penelitian ini adalah data Kuantitatif. Sumber data dalam penelitian ini adalah data sekunder. Sampel diambil dengan menggunakan teknik purposive sampling dengan kriteria sebagai berikut,

1. Perusahaan sektor properti, real estate dan konstruksi bangunan yang tercatat dalam Bursa Efek Indonesia tahun 2015 - 2019.

2. Perusahaan sektor properti, real estate dan konstruksi bangunan yang dapat diakses laporan tahunan lengkap berturut - turut selama periode penelitian.

Sampel diperoleh berdasarkan purposivesampling dan menghasilkan 43 perusahaan pada perusahaan sektor properti, real estate dan konstruksi banguanan untuk tahun fiskal 20152019 yang terdaftar di Bursa Efek Indonesia.

\section{Variabel Penelitian}




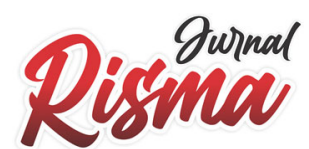

Vol. 1 No. 3 September 2021

Variabel Dependen sering disebut sebagai variabel output, kriteria, konsekuen. Dalam bahasa Indonesia sering disebut sebagai variabel terikat. Variabel terikat merupakan variabel yang dipengaruhi atau yang menjadi akibat, karena adanya variabel bebas (Sugiyono, 2019:69). Variabel dependen dalam penelitian ini adalah kinerja perusahaan. Kinerja perusahaan merupakan suatu hasil atau prestasi yang telah dicapai oleh perusahaan dalam menjalankan fungsinya dan pengelolaan perusahaan selama periode tertentu. Kinerja perusahaan diukur melalui Return On Equity. ROE merupakan imbal hasil atau tingkat pengembalian laba atas total ekuitas, yang menjadi ukuran kinerja perusahaan sekaligus pemegang saham (Kurniawan, 2017). Semakin tinggi Return On Equity semakin baik perusahaan dalam hal mendapatkan keuntungan. Semakin tinggi Return On Equity semakin efektif manajemen dalam memanfaatkan modal pemegang saham. laba bersih setelah pajak variabel bebas. Variabel bebas adalah variabel yang mempengaruhi atau yang menjadi sebab perubahaannya atau timbulnya variabel dependen (Sugiyono, 2019:69). Variabel Independen dalam penelitian ini adalah enterprise risk management.

Dalam penelitian ini Enterprise Risk Management (ERM) diukur indeks jumlah pengungkapan item ERM yang mengacu pada ERM Framework berupa 20 prinsip pengungkapan ERM yang mencakup 5 komponen yaitu Governance and Culture, Strategy and Objective-Setting, Performance, Review and Revision dan Information, Communication, and Reporting. Metode pengumpulan data yang digunakan untuk menganalisis pengungkapan ERM adalah content analysis. Perhitungan item-item menggunakan pendekatan dikotomi yaitu setiap item ERM yang diungkapkan diberi nilai 1, dan 0 apabila tidak diungkapkan. Informasi mengenai pengungkapan ERM diperoleh dari laporan keuangan(annual report) dan situs perusahaan (Meizaroh dan Lucyanda,2011). Proksi yang digunakan untuk mengukur pengungkapan ERM adalah indeks ERM disclosure (Devi, et al, 2017)

Variabel Independen sering disebutsebagai variabel stimulus, predictor, antecedent. Dalam bahasa Indonesia sering disebut sebagai Intellectual Capital. Intellectual Capital (IC) merupakan sebuah informasi dan pengetahuan yang dapat diaplikasikan ke dalam sebuah pekerjaan untuk dapat menciptakan sebuah nilai di dalam perusahaan (Lestari \& Sapitri, 2016). Intellectual capital diukur berdasarkan value added yang diciptakan oleh human capital, structural capital, dan costumer capital. Gabungan dari ketiga value added tersebut disebut dengan nama Value Added Intellectual Capital (VAIC ${ }^{T M}$ ). VAIC ${ }^{\mathrm{TM}}$ adalah metode untuk mengukur value added yang diberikan intellectual capital yang dikembangkan oleh Pulic. Pulic (1998) menyatakan bahwa $\mathrm{VAIC}^{\mathrm{TM}}$ dapat diukur dengan tahapan sebagai berikut.

\section{Tenik analisis data}

Teknik analisis data pada penelitian ini adalah regresi linier sederhana dan Moderated Regression Analysis (MRA) yang diolah dengan bantuan program SPSS. Pengujian dapat dilakukan setelah model dari penelitian ini memenuhi syaratyaitu data harus berdistribusi normal, tidak mengandung multikolinearitas, bebas dari autokorelasi, dan bebas dari heteroskedastisitas. Setelah melalui serangkaian pengujian tadi, barulah dilakukan uji regresi terhadap 2 model penelitian untuk menentukan apakah hipotesis diterima atau tidak diterima. Model pertama dan kedua dari penelitian ini sebagai berikut:

$\mathrm{ROE}=\alpha+\beta 1(\mathrm{ERM})+\varepsilon($ Persamaan hipotesis 1$)$ 
$\mathrm{ROE}=\alpha+\beta 1(\mathrm{ERM})+\beta 2(\mathrm{IC})+\beta 3(\mathrm{ERM} * \mathrm{IC})+\varepsilon$

(Persamaan hipotesis 2)

\section{HASIL DAN PEMBAHASAN Data Penelitian}

\begin{tabular}{|c|c|c|}
\hline & Reterangan & Jimlah perisahagri \\
\hline & 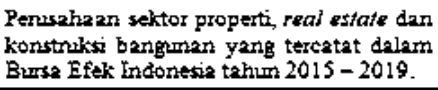 & 69 penusihan \\
\hline & 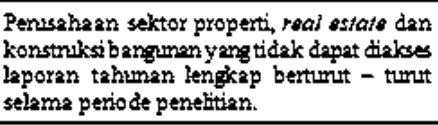 & (26) penusakash \\
\hline \multirow{2}{*}{\multicolumn{2}{|c|}{ enwehan dengan data lengap }} & 43 \\
\hline & & Stahm \\
\hline \multicolumn{2}{|r|}{ otal data pentitian $2015-2019=5 x+3$} & 215 observasi \\
\hline \multirow{2}{*}{\multicolumn{2}{|c|}{ atz obther }} & (26) observasi \\
\hline & & 189 observesi \\
\hline
\end{tabular}

Data penelitian yang digunakan dalam penelitian ini adalah perusahaan yang termasukdalam sektor properti, real estate dan konstruksi bangunan yang tercatat dalam Bursa Efek Indonesia. Periode yang diambil adalah tahun 2015-2019. Selama periode tersebut total perusahaan yang terdaftar sebanyak 69 perusahaan. Berdasarkan proses purposive sampling yang telah dilakukan, maka terdapat 43 perusahaan yang memiliki data lengkap. Dari 43 perusahaan tersebut dilakukanpenelitian selama lima tahun dari periode 2015-2019 sehingga data dari sampel penelitian adalah 215 data. Saat melakukan uji outlier ditemukan sebanyak 26 data yang menyimpang sehingga data yang dijadikan dalam observasi penelitian adalah sebanyak 189 data.

Tabel 4.2. Daftar Nama Perusahaan Xang Menjadi Sampel Penelitian

\begin{tabular}{|c|c|c|}
\hline Wo & Kode & Nama peruthan \\
\hline \multicolumn{3}{|c|}{ Perusahasn Froperti den Real Estate } \\
\hline 1 & APLN & Afeme Podomoro Land Tbk \\
\hline 2 & ASRI & Alam Sutera Realty Tbk \\
\hline 3 & BIKA & Bimakarya Jaya Abadi Tbk. \\
\hline 4 & BIPP & Bhuwantala Indah Perrui Tbk. \\
\hline 5 & BKDP & Bukit Darmo Property Thk. \\
\hline 6 & BKSL & Sentul City Tbk. \\
\hline$T$ & BSDE & Bumui Serpong Damai Thk. \\
\hline 8 & CTRA & Ciputra Developmert Thk. \\
\hline 9 & DILD & Intiland Development Thk \\
\hline 10 & DMAS & Puradelta Lestari Tbk. \\
\hline 11 & DUTI & Duta Pertiwi Tbk. \\
\hline 12 & FMII & Fortme Mate Indonesia Thk. \\
\hline 13 & GPRA & Pardana Gapraprima Tbk \\
\hline 14 & GWSA & Greenwood Sejahtera Tbk. \\
\hline 15 & IRPT & Jaya Real Property Tbk. \\
\hline 16 & LPKR & Lippo Karawaci Tbk. \\
\hline $1 \mathrm{~T}$ & MOLN & Moderrland Realty Tbk \\
\hline 18 & MMLP & Mega Manungeal Ptoperty Thk. \\
\hline 19 & MTLA & MetropolitanLand Tbk. \\
\hline 20 & MTSM & Metro Realty Thk. \\
\hline 21 & NTRO & City Retail Developments Thk. \\
\hline 22 & OMRE & Indonesia Prima Property Thk. \\
\hline 23 & PI.IN & Flaza Indonesia Realty Thk. \\
\hline 24 & PPRO & PP Properti Thk. \\
\hline
\end{tabular}

\begin{tabular}{|c|c|c|}
\hline 25 & PWON & Pakunion Ita TbK \\
\hline 26 & RBMS & 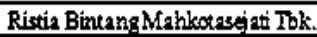 \\
\hline 27 & RDTX & Roda Viatex Tbk. \\
\hline 28 & RODA & Pikko Land Development Tbk. \\
\hline 29 & SMDML & Suryamas Dutamalomr Tbk. \\
\hline 30 & SMRA & Summarecos Agane Tbk. \\
\hline 31 & TARA & Sitaka Propetimdo Tbk. \\
\hline \multicolumn{3}{|c|}{ Pertushatan Konstrulali Bangunan } \\
\hline 32 & ACST & Asset Indonise Tbk \\
\hline 33 & ADHI & Adhi Kayn (Persero) Tbk. \\
\hline 34 & DGIK & Nusa Konstniks Enjimining Tok. \\
\hline 35 & IDPR & Indonesia Pondesi Rey Tbk \\
\hline 36 & JKON & $\begin{array}{l}\text { Jaya Konstrict Mangeala } \\
\text { Pratame Tbk. }\end{array}$ \\
\hline 37 & $\mathrm{NRCA}$ & Nusa RayaCinta Tbk. \\
\hline 38 & PTPP & PP (Persero) Tbk. \\
\hline 39 & SSLA & Surya Semesta Intemisa Tok. \\
\hline 40 & TOTL & Total BangmPersad Tbk \\
\hline 41 & WEGE & $\begin{array}{l}\text { Wijaya Karya Barguan Gtdma } \\
\text { Tbk. }\end{array}$ \\
\hline 42 & WIKA & Wijaya Karya(Persaro) Tbk. \\
\hline 43 & WSKT & Waskina Karva(Perserol Tbk. \\
\hline
\end{tabular}

\section{Statistik deskriptif}

Analisis statistika deskriptif dilakukan untuk mengetahui gambaran umum data yang digunakan 


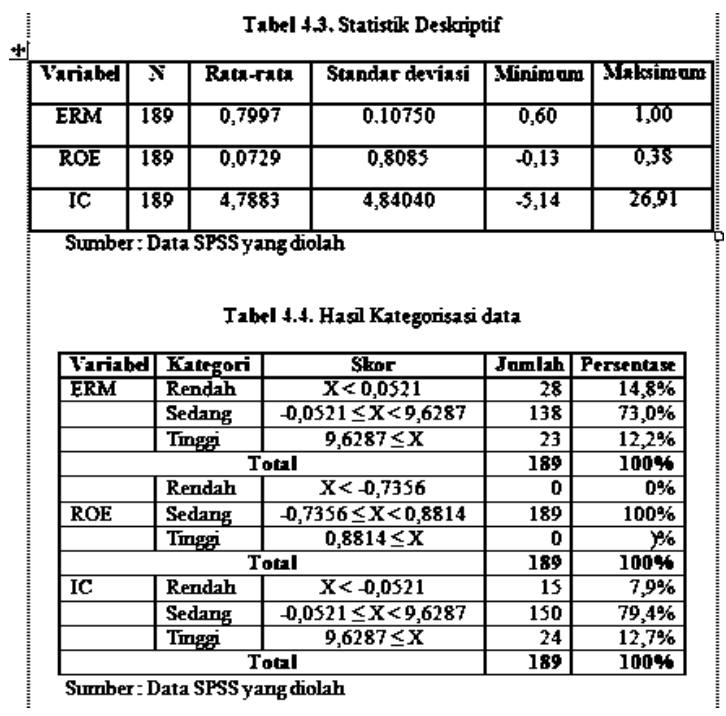

dalam penelitian tanpa mempengaruhi hasil akhir penelitian. Analisis dilakukan pada setiap variabel meliputi nilai minimum, maksimum, rata-rata, danstandar deviasi. Tabel 4.3 dan Tabel 4.4. berikut ini menunjukkan statistik deskriptif dan hasil kategorisasi data dari masing- masing variabel penelitian: menunjukkan bahwa secara umum tingkat pengungkapan ERM pada perusahaan property, real estate dan konstruksi banguanan tergolong sedang (sesuai rentang skor pada Tabel 4.4. sebesar 73,0\%). Kelonggaran ketentuan pengungkapan ERM tentang syarat minimum item pengungkapan ERM yang wajib diungkapkan oleh perusahaan property, real estate dan konstruksi bangunan menyebabkan perusahaan nonkeuangan kurang memperhatikan kelengkapan instrumen pengungkapan ERM dancenderung hanya menyajikan informasi yang bersifat umum.

Berdasarkan tabel di atas dapat dilihat bahwa jumlah data dari penelitian ini sebanyak 189 observasi. Variabel kinerja perusahaan memiliki nilai minimum $-0,13$ dan nilai maksimum sebesar 0,38. Nilai terendah dimiliki oleh PT. Binakarya Jaya Abadi Tbk (BIKA) pada tahun 2019 dan nilai tertinggi dimiliki oleh PT. Wijaya Karya Bangunan Gedung Tbk. (WEGE) pada tahun 2015. Nilai standardeviasi variabel kinerja perusahaan sebesar 0,8085. Hasil nilai rata-rata kinerja perusahaan berdasarkan perhitungan pada Tabel 4.3 yaitu sebesar 0,0729 (berada di antara rentang skor $-0,7356 \leq \mathrm{X}<0,8814$ ) menunjukkan bahwa secara umum tingkat pengungkapan ERM pada perusahaan properti, real estate dan konstruksi bangunan tergolong sedang (sesuai rentang skor pada Tabel 4.4).

Variabel pengungkapan Enterprise Risk Management memiliki nilai minimum 0,60 dan nilai maksimum 1,00. Nilai standar deviasi variabel Enterprise Risk Management sebesar 0.10750. Hasil nilai rata-rata pengungkapan ERM berdasarkan perhitungan pada Tabel 4.3. yaitu sebesar 0,7997 (berada di antara rentang skor $-0,0521 \leq \mathrm{X}<9,6287$

Variabel Intellectual Capital memiliki nilai minimum -5,14 dan nilai maksimum 26,91. Nilai terendah dimiliki oleh PT. City Retail Developments Tbk. (NIRO) pada tahun 2015 dan nilai tertinggi dimiliki oleh PT. Puradelta Lestari Tbk. (DMAS) tahun 2016. Nilai standar deviasi variabel IntellectualCapital sebesar 4,84040. Hasil nilai rata-rata tabel 4.3. pada variabel Intellectual Capital sebesar 4,7883 yang berarti bahwa kepatuhan 
perusahaan property, real estate dan konstruksi bangunan terhadap pengungkapan Intellectual Capital tergolong sedang sesuai rentang 79,4\% yang terdapat pada tabel 4.4. Perusahaan properti, real estate dan konstruksi bangunan sudah memiliki kesadaran dalam melakukan pengungkapan IC meskipun pengungkapan IC belum diatur dalam regulasi. Meskipun demikian, perusahaan nonkeuangan masih tetap harus meningkatkan kelengkapan instrumen pengungkapan IC dalam laporan tahunan.

\section{Uji Asumsi Klasik Uji Normalitas}

Menurut Ghozali (2005:110) Uji normalitasdilakukan untuk apakah di dalam model regresi

variabel independen dan variable dependen atau keduanya mempunyai distribusi normal atau tidak.

\begin{tabular}{|c|c|c|}
\hline Kriteria & Model 1 & Model 2 \\
\hline $\mathbf{N}$ & 189 & 189 \\
\hline Kobnogorov-snimov $\{\mathrm{K}-\mathrm{S}\rangle$ & 1,270 & 1,360 \\
\hline Signifikansi & 0,08 & 0,05 \\
\hline \multicolumn{3}{|c|}{ Sumber. DataSPSS yang diolah } \\
\hline
\end{tabular}

Berdasarkan tabel di atas diketahuisignifikansi uji Kolmogorov-Smirnov model 1 dengan menggunakan 189 data sebesar 0,08 dan model 2 sebesar 0,05 dan keduanya telah melebihi 0,05. Dengan demikian disimpulkan model 1 dan 2 berdistribusi normal.

\section{Uji Multikolinieritas}

Uji multikolinieritas dilakukan untuk mendeteksi apakah model regresi dalam analisis antar variabel bebas satu dengan variabel bebas yang lain salingberhubungan atau tidak.

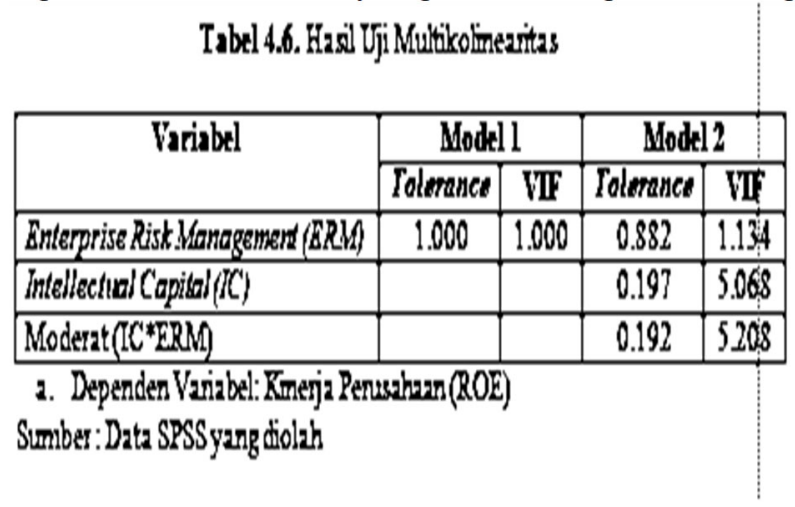

Berdasarkan hasil uji multikolinieritas yang tertera pada tabel diketahui bahwa nilai VIF untuk 2 model regresi semuanya telah lebih kecil dari nilai 10, begitu juga untuk nilai tolerance yang semua sudah lebih besar dari 0,1. Dengan demikian disimpulkan bahwa di dalam model regresi 1 dan 2 sudah terbebas dari pelanggaran atas asumsimultikolinieritas. Uji Autokorelasi

Autokorelasi muncul karena observasi yangberurutan sepanjang waktu berkaitan satu sama lain. 
Trbel 4.7. Hasil ugi Autokorelasi

\begin{tabular}{|c|c|c|}
\hline & dUDWe $-\mathrm{dU}$ & Keterangan \\
\hline Model!! & $1,783322,0602,21668$ & Tidak tenjadi Autokorelas \\
\hline Model 2 & $1,783322,016021668$ & Tidak teriadi Aurtokorelas \\
\hline
\end{tabular}

Sumber:Dita SPSSyangdolah

Berdasarkan pada hasil uji autokorelasi model regresi bahwa nilai durbin watson untuk model regresi pertama sebesar 2,060 dan untuk model kedua sebesar 2,016. Dikarenakan dua nilai durbin watson untuk model regresi telah berada di dalam rentang $\mathrm{d}$ $>\mathrm{dU}$ dan $\mathrm{d}<4$-dU, dengan demikian dapatdisimpulkan bahwa asumsi autokorelasi model regresi telah terpenuhi.

\section{Uji Heteroskedastisitas}

Uji heteroskedastisitas bertujuan untuk menguji apakah dalam model regresi terjadi ketidaksamaan varians dari residual satu pengamatan ke pengamatan yang lain (Ghozali, 2005:105).

\section{Regresi Linier Sederhana}

$\mathrm{ROE}=0,016+(-0,020) \mathrm{ERM}+\varepsilon$ (Persamaan hipotesis 1$)$

Untuk lebih meyakinkan bahwa tidak terdapat heteroskedastisitas dalam model regresi ini, maka dilakukan pula uji glejser. Uji glejser dilakukan dengan meregresi nilai absolut residual terhadap variabel independen (Ghozali, 2005).

\begin{tabular}{|c|c|c|}
\hline Mindel & Sig. & Kelernngan \\
\hline $\begin{array}{l}1 \text { (constant) } \\
\text { Enterprise risk monagenere }\end{array}$ & $\begin{array}{l}0,000 \\
0,336\end{array}$ & Bebasheteroskedastisita: \\
\hline $\begin{array}{l}2 \text { (constant) } \\
\text { Enroprise risk monogenort } \\
\text { Intellectwol Copitol } \\
\text { Moderat }\end{array}$ & $\begin{array}{l}0,000 \\
0,344 \\
0,195 \\
0,962\end{array}$ & Bebas heteroskedastisitat \\
\hline
\end{tabular}

Berdasarkan Tabel 4.8 angka Sig. $>$ 0,05atau 5\% yang berarti bahwa dalam model regresi ini tidak terdapat heteroskedastisitas.

Keterangan :

ROE : Kinerja Perusahaan $\alpha$ : Konstanta

$\beta 1 \quad$ : Koefisien regresi

ERM : Enterprise Risk Manajement

$\varepsilon \quad$ : Error term, yaitu tingkat kesalahanpenduga dalam penelitian.

Berdasarkan model regresi diatas, maka hasil regresi linear sederhana dapat dijelaskan sebagai berikut :

1. Koefisien-koefisien persamaan regresi linear sederhana diatas dapat diartikan koefisien regresi untuk konstan sebesar 0,016 menunjukkan bahwa jika variabel enterprise risk management bernilai nol maka kinerja perusahaan adalah 0,016 (dengan asumsi variabel lain dianggap konstan). 
2. Berdasarkan hasil persamaan regresi linearsederhana diatas dapat disimpulkan bahwa variabel dependen (Kinerja Perusahaan) akanmengalami kenaikan sebesar 0,016 tanpa dipengaruhi oleh semua variabel independen yang terdiri dari Enterprise Risk Management.

3. Nilai koefisien variabel Enterprise Risk Management adalah sebesar -0,020 yang berarti bahwa setiap penambahan sebesar $1 \%$ akan menyebabkan penurunan ROE sebesar -0,020\%(dengan asumsi bahwa variabel independen lain tetap).

Berdasarkan hasil pengujian hipotesis 1(H1) pada tabel 4.9. menunjukkan bahwa enterprise risk management tidak berpengaruh terhadap kinerja perusahaan yang artinya $\mathrm{H} 01$ diterima atau $\mathrm{Ha} 1$ ditolak pada signifikansi 5\%. Hal tersebut dapat dilihat dari hasil pengujian regresi sederhana yang menunjukkan nilai koefisien dari ERM bernilainegatif yaitu $-0,965$ dengan probabilitas sebesar

$0.336>0,05$. Berdasarkan bukti empiris, penelitian ini menyimpulkan bahwa penerapan ERM tidak berdampak pada kinerja perusahaan. Penerapan pengungkapan ERM masih dipandang oleh perusahaan hanya untuk mengikuti peraturan yangsudah ada dan belum memiliki hubungan langsung dengan peningkatan nilai perusahaan. Penerapan pengungkapan ERM menggunakan COSO masih baru di Indonesia sehingga masih memerlukan penyesuaian karena ERM adalah proses strategis yang berkesinambungan (Aditya \& Naomi 2017).

Temuan penelitian ini kontradiktif denganharapan teoritis penerapan praktik ERM memiliki dampak positif pada kinerja perusahaan dikonfirmasi oleh Shand and Lai (2019); Soliman dan Adam (2017); Florio dan Leoni (2016); Ahmed dan Manab (2016); Silva, Silva dan Chan (2016). Namun, temuan penelitian ini konsisten dengan yang lain peneliti yang menemukan bahwa ERM tidak memiliki implikasi nilai pada perusahaan. Misalnya, menurut Pagach et al. (2010), dalam studi mereka tentang "efek ERM pada kinerja perusahaan", hasil mereka gagal untuk mendukung proposisi bahwa ERM adalah penciptaan nilai. Demikian pula menurut Alawattegama (2018) dan Şenol dan Karaca (2017), temuan mereka gagal mendukung ekspektasi teoritis bahwa ERM memiliki dampak positif pada kinerja perusahaan.

Hasil penelitian ini menunjukkan bahwa signalling theory tidak dapat dibuktikan kebenarannya. Hal tersebut dikarenakan bahwa investor tidak menggunakan pengungkapan padasuatu informasi Enterprise Risk Management untuk melakukan pengambilan keputusan dalam melakukaninvestasi. Investor lebih cenderung melihat faktor lainuntuk mengambil keputusan berinvestasi, sepertirasio keuangan, kebijakan dividen, maupun harga saham.

\section{Moderated Regression Analysis (MRA)}

Moderated Regression Analysis (MRA) yang merupakan analisis dalam penelitian ini digunakan untuk memperoleh gambaran mengenai pengaruh Enterprise Risk Management pada kinerja perusahaan serta untuk menentukan apakah pemoderasi yaitu Intellectual Capital mempengaruhi hubungan antar variabel yaitu variabel terikat dan variabel bebas. Keunggulan dari uji interaksi ini adalah untuk mendapatkan hasil atas variabel moderasinya apakah memperkuat atau memperlemah pengaruh variabel terikat pada variabel bebas. Hasil moderated regression analysis (MRA) dalam penelitian ini dapat dilihat pada Tabel 4.10. berikut: 


\begin{tabular}{|c|c|c|c|c|c|}
\hline \multirow[b]{2}{*}{ Model } & \multicolumn{2}{|c|}{$\begin{array}{l}\text { Thatamdardized } \\
\text { Coeffeients }\end{array}$} & \multirow{2}{*}{$\begin{array}{c}\begin{array}{c}\text { Standardized } \\
\text { coefieients }\end{array} \\
\text { Beta }\end{array}$} & \multirow[b]{2}{*}{$\mathbf{T}$} & \multirow[b]{2}{*}{ Sig. } \\
\hline & $\overline{\mathbf{B}}$ & Std Erot & & & \\
\hline (constant) & 0,048 & 0,12 & & 3,980 & 0,020 \\
\hline $\begin{array}{ll}\text { Enterprist } \\
\text { mangerement }\end{array}$ & 0,021 & 0,22 & .0023 & 0,948 & 0,344 \\
\hline Inteflectral Capital & $-0,023$ & 0,18 & -0.218 & $-1,299$ & 0,195 \\
\hline Moderat (ERM* IC) & 0,001 & 0,22 & -0.008 & -0.047 & 0,962 \\
\hline Ad. R Square $\left(R^{2}\right)$ & \multicolumn{5}{|l|}{0.056} \\
\hline Signifikan F & \multicolumn{5}{|l|}{0,014} \\
\hline N⿴囗ai F & \multicolumn{5}{|l|}{3,651} \\
\hline
\end{tabular}

Model MRA dapat dilihat pada persamaan statistik seperti berikut.

$\mathrm{ROE}=0,048+(-0,021) \mathrm{ERM}+(-0,023) \mathrm{IC}+(-$

$0,001) \mathrm{ERM}^{*} \mathrm{IC}+\varepsilon($ Persamaan hipotesis 2$)$

Keterangan :

ROE : Kinerja Perusahaan $\alpha \quad$ : Konstanta

$\beta 1-\beta 3$ : Koefisien regresi

ERM : Enterprise Risk Manajement

IC : Intellectual Capital

ERM*IC: Interaksi antara enterprise risk manajemen

dengan Intellectual capital

$\varepsilon$ : Error term, yaitu tingkat kesalahanpenduga dalam penelitian.

Hasil ditambahnya interaksi antara variabel moderasi (Z) IC pada persamaan atau model kedua terjadinya sedikit perubahan pada pengaruh variabel ERM jika dibandingkan dengan hasil model pertama. Dari persamaan tersebut didapat hasil koefisienregresi variabel ERM sebesar -0,021 bertanda negatif dengan nilai signifikansi sebesar 0,344 atau lebih dari 0.05 sehingga variabel ini tidak memiliki pengaruh terhadap ROE dengan hubungan searah. Koefisienregresi dari variabel IC sebagai variabel moderasisebesar $-0,023$ bertanda negatif dan nilai signifikansi sebesar 0,195 maka dapat diartikan bahwa variabelini tidak memiliki pengaruh terhadap ROE dengan hubungan yang searah. Pada model kedua ini didapatkan juga apakah ada pengaruh interaksi antaravariabel independen dengan variable moderasi terhadap variabel dependen dengan nilai koefisien regresi untuk variabel interaksi antara ERM dengan IC (ERM*IC) sebesar $-0,001$ bertanda negatif danmemiliki nilai signifikansi sebesar 0,962, dapatdiartikan bahwa tidak terdapat pengaruh interaksi antara ERM dengan IC (ERM*IC) terhadap ROE dengan hubungan yang searah. Nilai dari uji $\mathrm{F}$ dalam penelitian ini yaitu sebesar 3,651 dengan signifikansi uji F sebesar $0.014<0.05$ yang artinya model ini signifikan dan dapat digunakan. Dari hasil moderating regression analysis didapatkan nilai R2 square sebesar 0.056 yang menunjukkan proporsi pengaruh ERM, IC dan Moderasi (ERM*IC) terhadap ROE sebesar 5,6\%. Artinya, pengaruh ERM, IC dan Moderasi (ERM*IC) terhadap ROEsebesar 5,6\% sedangkan sisanya 94,4\% dipengaruhi oleh variabel lain yang tidak ada di dalam modelmoderating regression analysis.

Hasil uji model parsial (uji t) memberikan nilai koefisien parameter -0,948 dengan sig. 0,344 untuk ERM artinya Ho1 diterima dengan kata lain tidak ada pengaruh ERM terhadap ROE. Hasil uji model parsial (uji t) memberikan nilai koefisien parameter -1,299 
dengan sig. 0,195 untuk IC artinya Ho2 diterima dengan kata lain tidak ada pengaruh IC terhadap ROE. Hasil uji model parsial (uji t) memberikan nilai koefisien parameter -0.047 dengan sig. 0,962 untuk moderasi(ERM*IC) artinya Ho3 diterima dengan kata lain IC tidak memoderasi hubungan ERM terhadap ROE. Jadi dapat disimpulkan bahwa tidak ada pengaruh enterprise risk management terhadap kinerja perusahaan dengan intellectual capital sebagai variable moderasi.

Berdasarkan hasil uji statistic hipotesis $2(\mathrm{H} 2)$ pada tabel 4.10 menunjukan nilai koefisien parameter -0.047 dengan sig. 0,962 yang artinya Intellectual Capital tidak memoderasi hubungan antara Enterprise Risk Management (ERM) dengan kinerja perusahaan dengan kata lain $\mathrm{H} 02$ diterima atau Ha2 ditolak pada signifikansi 5\%. Hasil hipotesisini konsisten dengan hipotesis sebelumnya bahwa pasar, dalam hal ini calon investor tidak memberikan nilai yang lebih tinggi terhadap perusahaan yang memiliki modal intelektual tinggi. Hal ini menunjukkan bahwa semakin tinggi nilai intellectual capital sebuah perusahaan, kinerja masa depan perusahaan tidak akan semakin tinggi. Belum adanya standar dalam pengukuran pengungkapan modal intelektual kemungkinan menyebabkan pasar belum mampu melakukan penilaian yang tepat atas pengungkapan modal intelektual perusahaan(Widarjo, 2011). Perusahaan di Indonesia lebihmemfokuskan diri dalam efisiensi penggunaan aktiva fisik dan keuangan untuk memberi kontribusi pada kinerja perusahaan. Perusahaan lebih fokus dalam efisiensi penggunaan aktiva fisik untuk meningkatkankinerja perusahaan karena investor lebih memandang seberapa besar aset yang dimiliki dan seberapa efisien perusahaan menggunakan aset fisik yang dimiliki daripada melihat bagaimana perusahaan mengelola aset tak terlihatnya seperti Intellectial Capital. Dengan demikian, penelitian ini belummampu membuktikan secara empiris bahwa pengungkapan Intellectual Capital dapat memoderasi hubungan antara enterprise risk management dengan kinerja perusahaan.

\section{KESIMPULAN}

Penelitian ini menganalisis pengaruh pengungkapan enterprise risk management (ERM) terhadap kinerja perusahaan. Penelitian ini bertujuan untuk mendapatkan bukti empiris pengaruh pengungkapan ERM terhadap kinerja perusahaan dengan intellectual capital (IC) sebagai variabel moderasi. Berdasarkan pengujian yang telah dilakukan pada bab sebelumnya, dapat disimpulkan sebagai berikut :

1. H01 diterima dan Ha1 ditolak, yang berarti "Tidak ada pengaruh enterprise risk management positif terhadap kinerja perusahaan atau hipotesis ditolak.

2. H02 diterima atau Ha2 ditolak yang berarti bahwa Intellectual Capital tidak memoderasi hubungan antara enterprise risk managemnet dengan kinerja perusahaan.

\section{IMPLIKASI PENELITIAN}

1. Dilihat dari kontribusi teoritis, hasil penelitian ini menunjukan bahwa teori signaling tidak dapat digunakan untuk menjelaskan pengaruh enterprise risk management terhadap kinerja perusahaan (diukur dengan ROE) dengan intellectual capital sebagai variable moderasi. Bisa terjadi karena pengungkapan informasi sensitive perusahaan ke pasar dan pesaing. Informasi management risiko yang sensitive tersebut terutama mempengaruhi pelanggan dan perspektif proses internal. Selain itu, ketika perusahaan memberikan tingkat identifikasi kejadian yang lebih tinggi, pemangku kepentingan, 
seperti pemegang saham, investor dan kreditor mungkin mulai panik dan meragukan pengambilan keputusan perusahaan.

2. Dilihat dari kontribusi praktis, hasil penelitian ini memberikan informasi tentang adopsi tidak berpengaruhnya enterprise risk management terhadap kinerja perusahaan dengan intellectual capital sebagai variable moderasi di Negara-Negara ekonomi berkembang yang literatur sebelumnya umumnya kurang.

3. Dilihat dari kebijakan, hasil penelitian ini bermanfaat untuk digunakan sebagai bahan pertimbangan bagi regulator untuk membuat aturan tentang instrumen pengungkapan enterprise risk management dan pengungkapan intellectual capital yang wajib dilaporkan untuk memperkecil adanya asimetri informasi khususnya bagi perusahaan properti, real estate dan konstruksi bangunan yang belum memiliki aturan khusus terkait haltersebut.

\section{SARAN DAN KETERBATASAN PENELITIAN}

1. Penelitian ini menggunakan sampel yang terbatas pada perusahaan sektor properti, real estate dan konstruksi bangunan yang terdaftar di Bursa Efek Indonesia, sehingga penelitian ini tidak dapat digeneralisasi pada jenis perusahaan lain. Peneliti selanjutnya disarankan menggunakan sampel yang lebihluas tidak hanya berasal dari perusahaanperusahaan yang termasuk sektor properti, real estate dan konstruksi bangunan saja, sehingga kesimpulan yang dihasilkan pada penelitian tersebut memiliki cakupan yang lebih luas.

2. Penelitian ini menggunakan periode pengamatan selama 5 tahun, yaitu dari tahun 20152019 disarankan peneliti selanjutnya menggunakan periode pengamatan yang lebih panjang dan lebih baru agar dapat melihat perbandingan keuangan yang baru serta menambah variasi populasi yang dapat mengurangi dampak sampel bias.

3. Proxy penelitian ini menggunakan ROE untuk mengukur kinerja perushaan, enterprise risk management diukur dengan prinsip coso 2017 dan variabel moderasi intellectual capital dikur dengan (VAICTM). Untuk penelitian selanjutnya mengganti proxy setiap variabel yang digunakan.

4. Grand Teori dalam penelitian ini hanya mengunakan signaling teori. Untuk penelitian selanjutnya bisa mengganti atau menambah grand teori menggunakan teori Stakeholder untuk menjelaskan pengaruh enterprise riskmanagement terhadap kinerja perusahaan.

Karena ERM dapat membantu meningkatkan kepercayaan pemegang saham dan investor dengan membangun proses yang membantu menstabikan hasil keuangan dan nonkeuangan dan membantu membantu meningkatkanpemahaman pemangku kepentingan tentang urusan perusahaan.

\section{DAFTAR PUSTAKA}

Aditya, O., \& Naomi, P. (2017). Penerapan manajemen risiko perusahaan dan nilai perusahaan di sektor konstruksi dan properti.Esensi: Jurnal Bisnis dan Manajemen, 7(2), 167-180.

Agista, Gissel Glenda \& Ni Putu Sri Harta Mimba.2017. Pengaruh Corporate Governance Structure Dan Konsentrasi Kepemilikan Pada Pengungkapan Enterprise Risk Management. E-Jurnal Akuntansi Universitas Udayana Vol.20.1. Juli (2017): 438466. Issn: 2302-8556 
Agustina, Linda dan Niswah Baroroh.2016. The Relationship Between Enterprise Risk Management (ERM) And Firm Value Mediated Through The Financial Performance. Review of Integrative Business and Economics Research, Vol. 5, no. 1, pp.128-138

Ahmed, Idris dan Norlida Abdul Manab.2016. Influence of Enterprise Risk Management Framework Implementation and Board Equity Ownership on Firm Performance in Nigerian Financial Sector: An Initial Finding. IOSR Journal of Business and Management (IOSR-JBM) e-ISSN: 2278-487X, p-ISSN: 2319-7668. Volume 18, Issue 1.Ver.II (Jan. 2016), PP 61-68 www.iosrjournals.org.

Alawattegama, Kingsley Karunaratne.2018. The Impact of Enterprise Risk Management on Firm Performance: Evidence from Sri Lankan Banking and Finance Industry. International Journal of Business andManagement; Vol. 13, No. 1; 2018 ISSN 18333850 E-ISSN 1833-8119

Azwar,S. 2012. Penyusunan Skala Psikologis edisi 2. Yogyakarta: Pustaka Pelajar

Committee of Sponsoring Organizations of the Treadway Commission. 2004. EnterpriseRisk Management -Integrated Framework, September 2004.

Committee of Sponsoring Organizations of the Treadway Commission. 2017. EnterpriseRisk Management Framework - Integrating with Strategy and Performance.

Devi, Sunitha; I Gusti Nyoman Budiasih dan I Dewa Nyoman Badera.2017.Pengaruh Pengungkapan Enterprise Risk Management dan Pengungkapan Intellectual Capital terhadap Nilai Perusahaan. Jurnal Akuntansi dan Keuangan Indonesia, 20-45. http://dx.doi.org/ 10.21002 /ja ki. 2017.02.

Eikenhout, Lodewijk.2015. Risk Management and Performance in Insurance Companies (Master thesis). MSc in Business Administration.

Florio, Cristina dan Giulia Leoni. 2016. Enterprise risk management and firm performance: The italia Case. The British Accounting Review49 (2017) 56e74 www.elsevier.com/locate/bar

Ghozali, Imam. 2005. Aplikasi Analisis Multivariate dengan program SPSS. Semarang: Badan Penerbit Universitas Diponogoro.

Indriantoro, Nur \& Bambang Supomo. 2018. Metodologi Penelitian Bisnis untukAkuntansi dan Managemen. C.V ANDIOFFSET:Yogyakarta

Kencana, Maulandy Rizky Bayu. 18 Sep 2019, 18:20WIB. Pertumbuhan Industri Properti yangCepat Berdampak Besar ke Ekonomi.Diakses tanggal 12-25 2019dari https://www.liputan6.com/bisnis/read/4065907/pertumbuhan-industri-properti yang- cepat-berdampak-besar-ke-ekonomi

Khan, Sajjad Nawaz \& Engku Ismail Engku Ali. 2017. The Moderating Role of Intellectual Capital between Enterprise Risk Management and Firm Performance: A Conceptual Review. American Journal of Social Sciences and Humanities Vol. 2, No1, 9-15, 2017

Khan, Sajjad Nawaz \& Engku Ismail Engku Ali, Kaleem Anjum \& Muhammad Noman. 2019. Enterprise Risk Manjement and Firm Performance in Pakistan: Interaction Effect of Intellectual Capital. International Journal of Multidisciplinary and Current ResearchISSN: 231-3124

Kurniawan, Rivan. 2017. Rasio Fundamental: ROAdan ROE. Diakses 26 Januari 2020 dari http://rivankurniawan.com/2017/11/21/apa-itu-roa/

Kurniawan, Rivan. 2019.Prospek sektor property tahun di 2019. Diakses 2 Sptember 2020 
darihttp://rivankurniawan.com/2019/03/05/sektor-properti-di-2019/

Kusumawardani, Media. 2012. "Pengaruh Size, Kemakmuran, Ukuran Legislatif, Leverage terhadap Kinerja Keuangan Pemerintah Daerah di Indonesia". Dalam Accounting Analysis Journal, Vol. 1, No. 1, Hlm. 27-35, Agustus. Semarang: Fakultas Ekonomi Unnes.

Lestari,Nanik dan Rosi Candra Sapitri.2016.Pengaruh Intellectual Capital terhadap nilai perusahaan. Jurnal Akuntansi, Ekonomidan Manajemen Bisnis Vol. 4, No. 1, July 2016, 28-33 p-ISSN: 2337-7887

Meizaroh, \& Lucyanda, J. (2011). Pengaruh Corporate Governance dan Konsentrasi Kepemilikan pada Pengungkapan Enterprise Risk Management. Jurnal Akuntansi dan Keuangan, 1(Juli), 1-30. 1338.

Mirza, Sidra Ali and Attiya Javed. 2013.Determinants of financial performance of a firm: Case of Pakistani stock market. Journal of Economics and International Finance Vol. 5(2), pp. 43-52, May, 2013 DOI: 10.5897/JEIF12.043 ISSN 2006-9812 (C2013 Academic Journalshttp://www.academicjournals.org/JEIF

Oktari,I.G.A.P., Handayani, Lilik., Widiastuty, Erna.2016.Determinan Modal Intellectual (Intellectual Capital) Pada Perusahaan Publikkdi Indonesia Dan Impliikasinya Terhadap Nilai Perusahaan.Lampung,Simposium Nasional Akuntansi (SNA) XIX.

Pagach, Don dan Richard Warr.2010. The Effects of Enterprise Risk Management on Firm Performance. Jenkins Graduate School of Management North Carolina State University Raleigh, NC 27695 Electronic copy available at: http://ssrn.com/abstract $=1155218$

Pulic, A. (1998). Measuring the Performance of Intellectual Potential in Knowledge Economy. In The 2nd McMaster World Congress on Measuring and Managing Intellectual Capital by The Austrian Team for Intellectual Potential (pp. 1-20).

Priantara, Diaz.2017. Mengenal Kerangka KerjaEnterprise Risk Management Ala COSO. Diakses tanggal 24 Februari 2020 darihttps://www.wartaekonomi.co.id/read15515 3/mengenal-kerangka-kerja-enterprise-risk- management-ala-coso

Riahi-belkaoui, A. (2003). Intellectual Capital andFirm Performance of US Multinational Firms A Study of The Resource-Based andStakeholder Views. Journal of IntellectualCapital. https://www.researchgate.net/publication/22 8306555

Şenol, Zekai \& suleyman serdar karaca. 2017. TheEffect of Enterprise Risk Management on Firm Performance: A Case Study on Turkey.Financial Studies, 21(2).

Shad, Muhammad Kashif \&Fong-Woon Lai.2019. Enterprise Risk Management Implementation and Firm Performance: Evidence from the Malaysian Oil and Gas Industry. International Journal of Business and Management; Vol. 14, No. 9; 2019 ISSN 1833-3850E-ISSN 1833-8119 Published by Canadian Center of Scienceand Education.

Silva, Juliano Rodrigues;Aldy Fernandes da Silva dan Betty Lilian Chan .2016. Enterprise risk management and firm performance: evidences from Brazil. Congresso UnB de contabilidade e governance DE 23 A25 De Novembro 2016-brasilia,DF

Siregar, Nolita Yeni dan Tiara Amelia Safitri.2019. Pengaruh Pengungkapan Enterprise Risk Management Intellectual Capital, Corporate Social Responsibility, Dan Sustainability Report Terhadap Nilai Perusahaan. Jurnal Bisnis Darmajaya, Vol. 05. 
No. 02, Juli 2019 197308\%2987\%3A3\%3C355\%3AJMS\%3E2.0.CO\%3B2-3

Soliman, Alaa dan Mukhtar Adam. 2017. Enterprise $\quad$.2017. [ERM UPDATE 2017] What you needRisk Management and firm performance: an integrated model for the banking sector Banks and Bank Systems, Volume 12, Issue 2, 2017.

Spence, Michael. 1973. The Quarterly Journal of Economics, Vol. 87, No. 3. (Aug., 1973), pp. 355-374.Stable URL: http://links.jstor.org/sici?sici=00335533\%28to know about the framework changes toEnterprise Risk Management. Diakses tanggal 24 Februari 2020 darihttps://pfcaccounting.com/2017/10/31/erm- update-2017-whatyou-need-to-know-about-the-framework-changes-to-enterprise-risk- management/

Sugiyono, 2019. Edisi 2: Metode Penelitian Kuantitatif Kualitatif dan R\&D. Alfabet:Bandung

Susmianti. 2019. Buletin Kinerja mengawalperubahan Edisi XL/Semester II .2019. Biro Perencanaan dan Keuangan SekretariatJenderal Kementerian Keuangan.

Tari, Dwi Nicken. 29 Oktober 2019. Indeks Sektor Properti dan Infrastruktur Melaju, Simak Rekomendasi MNC Sekuritas. Diakses 12- 25-2019 dari https://market.bisnis.com/read/20191029/189/1164253/indeks-sektor-properti-daninfrastruktur-melaju-simak-rekomendasi- mnc-sekuritas

Ulum, Ihayaul.2009.Intellectual Capital (konsep dan kajian empiris). Yogyakarta: Graha ilmu

Widarjo, W. (2011) Pengaruh modal intelektual dan pengungkapan modal intelektual pada nilai perusahaan. Simposium Nasional Akuntansi XIV, Aceh 